Available online at http://journal.stkip-andi-matappa.ac.id/index.php/histogram/index

Histogram: Jurnal Pendidikan Matematika 4(2)., 2020, 387- 397

\title{
ANALISIS KESULITAN MAHASISWA DALAM MENYELESAIKAN SOAL BILANGAN RIIL
}

\author{
Sri Novia Martin ${ }^{*}$, Meria Ultra Gusteti ${ }^{2}$ \\ 1,2 STKIP Adzkia
}

* Corresponding Author. Email: noviamart@stkipadzkia.ac.id

Received: 25 Juli 2020; Revised: 15 September 2020 ; Accepted: 30 September 2020

\section{ABSTRAK}

Analisis Riil adalah mata kuliah wajib bagi mahasiswa semester 5 program studi pendidikan Matematika di STKIP Adzkia. Penelitian ini bertujuan untuk mengetahui kesulitan belajar yang dialami oleh mahasiswa STKIP Adzkia pada mata kuliah bilangan riil. Penelitian ini merupakan penelitian kualitatif. Subjek penelitian yaitu mahasiswa program studi pendidikan Matematika STKIP Adzkia semester 5. Data diperoleh dari hasil tes. Data yang sudah diperoleh dianalisis dengan tiga langkah yaitu reduksi data, penyajian data dan penarikan kesimpulan. Kesulitan yang dialami mahasiswa dapat dilihat dari kesalahan yang dilakukan mahasiswa ketika menyelesaikan soal bilangan riil. Hasil penelitian ini menunjukkan bahwa kesulitan-kesulitan yang dialami mahasiswa pada materi bilangan riil yaitu: (1) kesulitan dalam menerapkan konsep; (2) Kesulitan mengembangkan konsep yang sudah dipelajari; (3) kesulitan dalam melakukan operasi hitung;(4) kesulitan dalam menggunakan prosedur tertentu; (5) kesulitan untuk mengkonstruksi ide atau gagasan untuk membuktikan suatu pernyataan Matematika. Hasil penelitian ini menunjukkan banyaknya kesulitan yang dihadapi mahasiswa program studi pendidikan Matematika STKIP Adzkia dalam menyelesaikan soal bilangan riil.

Kata Kunci: analisis, kesulitan Mahasiswa, bilangan Riil

\begin{abstract}
Real Analysis is a compulsory subject for students in the 5th semester of the Mathematics education study program at STKIP Adzkia. This study aims to determine the learning difficulties experienced by students of STKIP Adzkia in riil number courses. This research was qualitative research. The research subjects were students of Mathematics STKIP Adzkia 5th semester study program. Data were obtained from observations and tests. The steps of ata analysis techniques were data reduction, data presentation, and conclusion drawing. Difficulties experienced by students could be seen from the mistakes made by students when solving riil number problems. The results of this study indicated that the difficulties experienced by students in the material of riil numbers were (1) difficulties in applying the concept; (2) Difficulties in developing concepts that have already been learned; (3) difficulty in performing arithmetic operations; (4) difficulty in using certain procedures; (5) difficulty in constructing ideas or ideas to prove a Mathematical statement.This indicates that there are many difficulties in learning real analysis.
\end{abstract}

Keywords: analysis, student difficulties, riil numbers

How to Cite: Martin, S, N., \& Gusteti, M, U. (2020). Analisis Kesulitan Mahasiswa Dalam Menyelesaikan Soal Bilangan Riil. Histogram: Jurnal Pendidikan Matematika, 4(2), 387 - 397, doi: http://dx.doi.org/10.31100/histogram.v4i2.694

Permalink/DOI: http://dx.doi.org/10.31100/histogram.v4i2.694

\section{PENDAHULUAN}

Analisis riil merupakan mata kuliah wajib yang diberikan kepada mahasiswa Semester 5 pada Program studi Pendidikan Matematika STKIP Adzkia. Mata kuliah ini memiliki bobot 3 SKS. Materi yang dipelajari pada mata kuliah Analisis Riil secara garis

Copyright(C) 2020, THE AUTHOR (S). This article distributed under the CC-BY-SA-license. 


\section{Histogram: Jurnal Pendidikan Matematika, 4 (2), 2020 - 388 Faíz Azmi Fauzia $^{1^{*}}$, Junaidi Fery Efendi ${ }^{2}$}

besar yaitu pengantar bilangan riil, sifat-sifat bilangan riil dan Barisan bilangan riil. Mata kuliah Analisis Riil menekankan kepada mahasiswa agar menguasai pemahaman konsep dan pembuktian teorema terkait dengan bilangan riil, fungsi, limit dan barisan ( Sari, 2017). Pada mata kuliah ini mahasiswa diberikan konsep berupa definisi-definisi, sifat dan teorema-teorema yang berlaku pada bilangan Riil. Selanjutnya Mahasiswa dilatih untuk bagaimana menyelesaikan persoalan/permasalahan Analisis Riil dengan menggunakan konsep yang sudah dipelajari tersebut. Selain itu materi yang dibahas pada mata kuliah bilangan riil juga syarat akan pembuktian-pembuktian. Baik pembuktian teorema maupun pembuktian suatu pernyataan Matematika.

Mahasiswa bisa memperoleh hasil belajar maksimal apabila mahasiswa bisa memahami konsep dengan baik serta mampu melakukan pembuktian dengan benar. Pemahaman konsep sangat penting karena merupakan dasar untuk mengembangkan kemampuan matematika yang lainnya (Gusteti \& Syafti, 2018). Sementara itu pembuktian sangat penting untuk membuktikan suatu kebenaran pernyataan Matematika. Akan tetapi pada kenyataannya masih banyak mahasiswa mengalami kesulitan dalam memahami konsep dan melakukan pembuktian riil.

Ada beberapa kesulitan yang dialami mahasiswa dalam belajar Analisis Rill. Sucipto dan Mauliddin (2017) mengungkapkan bahwa kesulitan mahasiswa dalam belajar Analisis Riil yaitu: maksud soal yang sulit dipahami mahasiswa, sulit untuk memulai suatu pembuktian, sulit menentukan ide atau gagasan yang tepat untuk melakukan pembuktian, sulit menerapkan definisi, sifat, dan teorema untuk mengkonstruksi suatu pembuktian secara tepat, dan sulit menentukan langkah-langkah pembuktian yang benar.

Mahasiswa mengalami kesulitan dalam melakukan pembuktian. Kesulitan melakukan pembuktian disebabkan oleh berbagai faktor. Moore dalam Spronsen (2008) mengungkapkan bahwa penyebab mahasiswa mengalami kesulitan dalam menyusun bukti yaitu mahasiswa tidak paham sehingga tidak mampu memberikan defenisi, terbatasnya intuisi mahasiswa tentang konsep, kurang memadainya gambaran konsep mahasiswa untuk menyusun pembuktian, tidak ada kemauan dan kemampuan membuat contoh untuk memperjelas pembuktian, ketidaktahuan mahasiswa menyusun bukti lengkap dengan memanfaatkan definisi, ketidakmampuan menggunakan bahasa dan notasi matematis, dan ketidaktahuan mahasiswa cara mengawali pembuktian. Hal ini sejalan dengan apa yang diungkapkan oleh Siregar (2019) bahwa kesulitan mahasiswa dalam menyelesaikan soal bilangan riil yakni sulit menentukan permulaan dari suatu pembuktian, sulit menerapkan 


\section{Histogram: Jurnal Pendidikan Matematika, 4 (2), 2020 - 389 Faíz Azmi Fauzia ${ }^{*}$, Junaidi Fery Efendi ${ }^{2}$}

dan menyatakan definisi dan sifat sesuai dengan bahasa sendiri sehingga sulit untuk mengungkapkan ide. Penyebab lain yang membuat mahasiswa kesulitan dalam pembuktian menurut Wahyuni (2017) adalah miskonsepsi mahasiswa terhadap materi analisis riil. Jika mahasiswa salah memahami konsep maka mahasiswa juga mengalami kesulitan dalam melakukan pembuktian.

Siregar (2019) dalam penelitiannya juga menemukan bahwa mahasiswa tidak mampu menuliskan dan menerapkan konsep dan tidak mampu mentranfer pengetahuan yang ada. Hal ini sejalan dengan apa yang juga diumgkapkan oleh Yuliana (2017) bahwa mahasiswa kesulitan dalam mentransfer pengetahuan dan melakukan operasi hitung dalam menyelesaikan soal pada materi barisan bilangan rill. Dari hasil penelitiannya terlihat bahwa ketidakmampuan mahasiswa dalam mentransfer pengetahuan yaitu mahasiswa tidak mampu menerapkan konsep yang sudah dipelajari untuk menyelesaikan soal atau permasalahan. Jadi dapat disimpulkan bahwa mahasiswa mengalami kesulitan dalam mentransfer pengetahuan yang ada untuk menyelesaikan persoalan Analisis Riil.

Mahasiswa juga mengalami kesulitan dalam menggunakan simbol-simbol matematika yang ada pada materi bilangan riil. Padahal pada materi bilangan riil banyak terdapat simbol-simbol Matematika. Hal ini sesuai dengan apa yang diungkapkan oleh Musliadi (2016) bahwa mahasiswa kurang paham menggunakan simbol yang tepat ketika membuat penyataan-pernyataan. Mahasiswa terkadang masih keliru dalam menggunakan simbol-simbol matematika ketika membuat pemisalan dalam sebuah pembuktian.

Berdasarkan teori yang sudah ada dan berdasarkan hasil observasi dilapangan yang menunjukkan banyaknya kesulitan yang dihadapi mahasiswa dalam pembelajaran analisis riil dan dalam menyelesaikan soal analisis riil. Kemudian ditambah dengan rendahnya hasil ujian yang diperoleh oleh mahasiswa prodi Pendidikan Matematika Semester 5 STKIP Adzkia ketika Ujian Tengah Semester(UTS), maka peneliti ingin melakukan sebuah kajian analisis kesulitan mahasiswa prodi pendidikan Matematika di STKIP Adzkia dalam menyelesaikan soal bilangan riil. Walaupun sudah ada yang melakukan penelitian tersebut di kampus lain, akan tetapi mahasiswa di setiap kampus memiliki tingkat kecerdasan dan latar belakang yang berbeda. Karena itu peneliti tertarik untuk meneliti ini di program studi Pendidikan Matematika STKIP Adzkia Penelitian ini diharapkan dapat memberikan gambaran bagi dosen Matematika/Pendidikan Matematika khususnya yang mengampu mata kuliah Analisis Riil tentang kesulitan yang dialami mahasiswa dalam pembelajaran Analisis Riil sehingga kesulitan tersebut bisa dicarikan solusi yang tepat. 


\section{Histogram: Jurnal Pendidikan Matematika, 4 (2), 2020 - 390 \\ Faíz Azmi Fauzia ${ }^{*}$, Junaidi Fery Efendi ${ }^{2}$}

\section{METODE PENELITIAN}

\section{A. Tempat dan Waktu}

Penelitian ini dilakukan di STKIP Adzkia Sumatera Barat. Subjek penelitian yaitu mahasiswa program studi pendidikan Matematika Semester 5 yang berjumlah 5 orang. Penelitian dilakukan selama sebulan, mulai dari observasi awal, pembuatan soal tes, dan pelaksanaan tes.

\section{B. Rancangan Penelitian}

Jenis penelitian ini adalah penelitian kualitatif. Tahapan pada penelitian kualitatif diawali dengan mencari makna objek-objek, berbagai bentuk pola, penjelasan, berbagai kemungkinan konfigurasi, alur sebab akibat, dan proposisi (Patilima, 2011). Pada penelitian ini data diperoleh dari observasi dan hasil tes. Hasil observasi dicatat dalam sebuah catatan anekdot yang kemudian akan dianalisis secara kualitatif. Sementara itu dari hasil tes akan diperoleh jawaban mahasiswa. Jawaban Mahasiswa tersebut dianalisis sesuai dengan analisis data kualitatif. Menurut Miles and Huberman dalam Sugiono (2016) terdapat 3 tahapan yang dilakukan untuk menganalisis data kualitatif yaitu data reduction (reduksi data), data display (penyajian data), conclution drawing/verification (menarik kesimpulan).

Patilima (2011) menjelaskan bahwa reduksi data merupakan suatu proses pemilihan dan penfokusan pada penyederhanaan, proses pengabstrakan, dan pentransformasian data yang ditemukan pada catatan lapangan. Maksudnya reduksi data sebagai suatu proses memilih data yang penting/diperlukan untuk penelitian serta membuang data yang tidak penting/diperlukan. Reduksi data dapat dilakukan semenjak pengumpulan data hingga penulisan laporan akhir penelitian. Pada penelitian ini reduksi data yaitu dilakukan pada jawaban mahasiswa. Jawaban mahasiswa yang diperoleh dibandingkan dengan teori yang sudah ada untuk dianalisis.

Tahap berikutnya adalah penyajian data. Menurut Miles and Huberman dalam Patilima (2011) penyajian data adalah susunan sekumpulan informasi yang memungkinkan adanya penarikan kesimpulan. Dengan kata lain penyajian data yaitu menyajikan data yang diperoleh dari lapangan berupa dokumentasi, hasil observasi, dan wawancara berupa uraian singkat. Penyajian data pada penelitian kualitatif biasanya menggunakan teks naratif. Pada penelitian ini, setelah jawaban mahasiswa direduksi selanjutnya disajikan dalam bentuk penjelasan naratif dan deskriptif. 


\section{Histogram: Jurnal Pendidikan Matematika, 4 (2), 2020 - 391 Faíz Azmi Fauzia $^{1}$, Junaidi Fery Efendi ${ }^{2}$}

Tahap terakhir dari analisis data kualitatif adalah penarikan kesimpulan dan verifikasi. Patilima (2011) menjelaskan bahwa kesimpulan akhir bergantung pada besarnya atau banyaknya catatan lapangan yang terkumpul, pengkodean, penyimpanan, dan metode pencarian ulang yang dipakai, kecakapan dan keuletan peneliti. Verifikasi atau pembuktikan ulang dilakukan untuk mencari persetujuan dan pembenaran, sehingga diperoleh validitas. Penarikan kesimpulan merupakan suatu yang sangat penting pada penelitian kualitatif karena kesimpulan merupakan jawaban dari pertanyaan penelitian. Pada penelitian ini dari penyajian data serta uraian singkat maka diperoleh suatu kesimpulan yang berupa kesulitan yang dialami mahasiswa dalam menyelesaikan soal-soal analisis riil.

\section{HASIL DAN PEMBAHASAN}

Hasil jawaban mahasiswa terhadap tes yang diberikan memberikan gambaran tentang kesulitan yang dihadapi mahasiswa ketika menyelesaikan soal bilangan riil. Hasil penelitian ini menunjukkan bahwa kesulitan-kesulitan yang dialami mahasiswa pada materi bilangan riil yaitu: (1) kesulitan dalam menerapkan konsep; (2) Kesulitan mengembangkan konsep yang sudah dipelajari; (3) kesulitan dalam melakukan operasi hitung;(4) kesulitan dalam menggunakan prosedur tertentu; (5) kesulitan untuk mengkonstruksi ide atau gagasan untuk membuktikan suatu pernyataan Matematika.

\section{A. Kesulitan dalam Menerapkan Konsep}

Memahami konsep adalah salah satu tujuan pembelajaran Matematika. Kemampuan pemahaman konsep adalah kemampuan dasar yang harus dikuasai oleh mahasiswa dalam proses belajar. Mahasiswa tidak akan bisa memecahkan suatu permasalahan matematika jika tidak memahami konsep. Mahasiswa juga kesulitan menggunakan keterampilan berfikir matematis yang lain seperti komunikasi matematis, penalaran, kritis dan kreatif apabila tidak menguasai konsep.

Meskipun pemahaman konsep adalah kemampuan dasar yang harus dimiliki mahasiswa, masih ada mahasiswa yang belum menguasai konsep dengan baik. Bahkan ada mahasiswa yang lupa konsep. Berikut contoh jawaban siswa pada soal tentang Himpunan:

Misalkan A, B dan C adalah himpunan, buktikan

$A \backslash(B \cap C)=(A \backslash B) \cup(A \backslash C)$.

Jawaban siswa dapat dilihat pada gambar 1 berikut: 
Histogram: Jurnal Pendidikan Matematika, 4 (2), 2020 - 392

Faíz Azmi Fauzia ${ }^{*}$, Junaidi Fery Efendi ${ }^{2}$

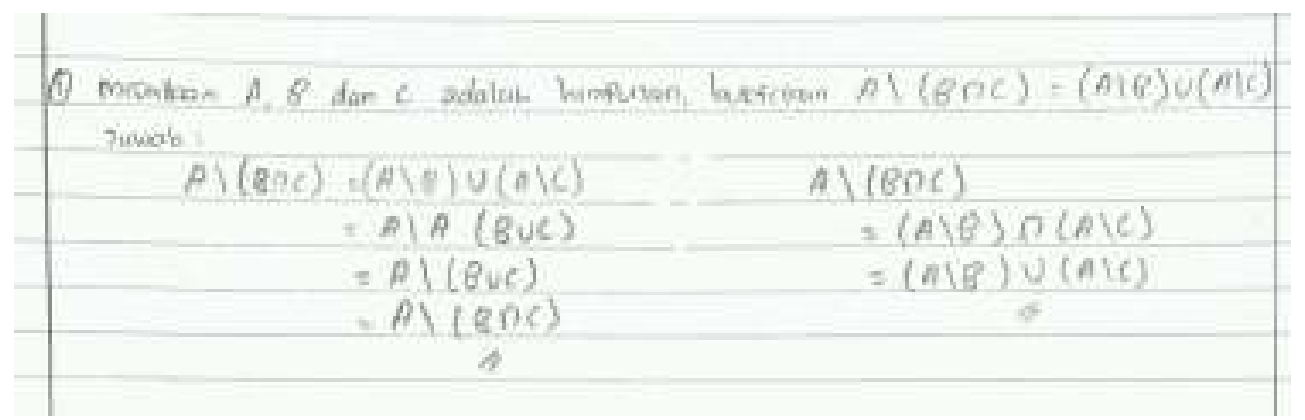

Gambar 1. Jawaban Mahasiswa mengenai Soal Himpunan

Jawaban mahasiswa pada Gambar 1 belum tepat. Dari jawaban mahasiswa tersebut terlihat bahwa mahasiswa lupa konsep tanda " =" (sama dengan) pada himpunan. Pembuktian dengan tanda " = " pada himpunan artinya bahwa pernyataan tersebut harus dibuktikan dua arah yaitu pertama harus dibuktikan bahwa $\boldsymbol{A} \backslash(\boldsymbol{B} \cap \boldsymbol{C}) \subset$ $(\boldsymbol{A} \backslash \boldsymbol{B}) \cup(\boldsymbol{A} \backslash \boldsymbol{C})$, kemudian yang kedua dibuktikan bahwa $(\boldsymbol{A} \backslash \boldsymbol{B}) \subset(\boldsymbol{A} \backslash \boldsymbol{C}) \boldsymbol{A} \backslash(\boldsymbol{B} \cap \boldsymbol{C})$.

Jika kedua bukti sudah memenuhi artinya pernyataan pada soal tersebut bernilai benar.

\section{B. Kesulitan Mengembangkan Konsep}

Dalam pembelajaran Matematika mahasiswa dituntut tidak hanya mengetahui konsep suatu materi akan tetapi juga bisa mengembangkan konsep tersebut ketika menyelesaikan soal. Mahasiswa dituntut memahami keterkaitan antar konsep karena ketika menyelesaikan suatu persoalan Matematika bisa jadi tidak hanya menggunakan satu konsep saja akan tetapi gabungan dari beberapa konsep Matematika.

Berikut ini adalah soal tentang nilai mutlak.

Gambarlah grafik $|x|+|y|=1$ pada bidang $\boldsymbol{R}^{2}$ !

Jawaban salah seorang siswa dapat dilihat dari gambar 2 berikut:

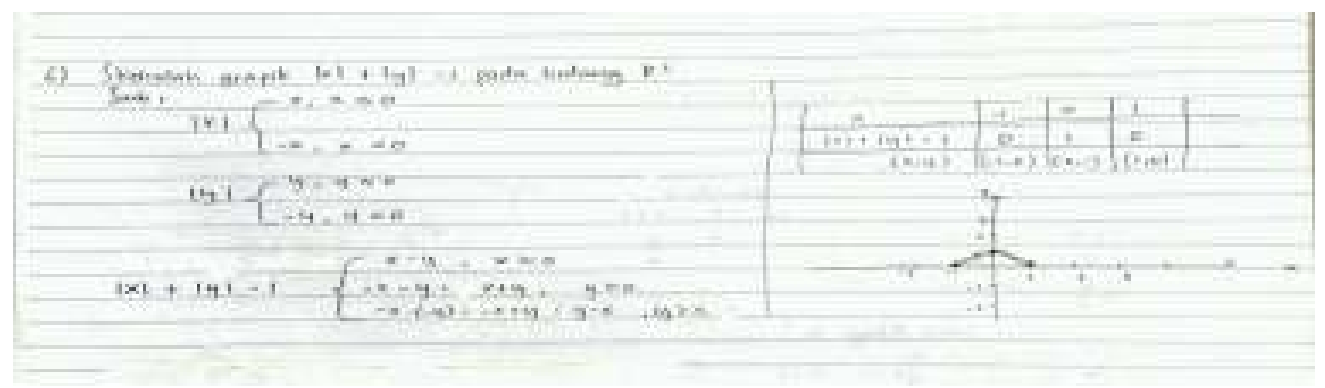

Gambar 2. Jawaban Mahasiswa Mengenai Soal Nilai Mutlak 
Histogram: Jurnal Pendidikan Matematika, 4 (2), 2020 - 393

Faíz Azmi Fauzia $^{1^{*}}$, Junaidi Fery Efendi ${ }^{2}$

Dari jawaban siswa tersebut terlihat bahwa mahasiswa sudah memahami konsep nilai dari $|x|$ dan $|y|$ dan sudah bisa mendefenisikannya dengan benar. Akan tetapi ketika yang ditanyakan adalah $|x|+|y|=1$, maka mahasiswa kesulitan mengembangkan konsep yang sudah diperoleh untuk menyelesaikan permasalahan tersebut.

C. Kesulitan dalam Memilih atau Melakukan Operasi Hitung

Matematika tidak lepas dari operasi dan angka-angka. Dalam Matematika sangat diperlukan ketelitian dan kehati-hatian baik dalam menerapkan konsep maupun dalam perhitungan. Kesalahan pada operasi bisa menyebabkan kesalahan pada hasil akhir. Tapi masih ada mahasiswa yang kurang teliti dan hati-hati dalam memilih pengoperasian yang dilakukan.

Berikut adalah soal tentang fungsi

Diketahui $f: R \rightarrow R$. Buktikan $f(x)=\frac{2 x-3}{2}$ adalah fungsi injektif!

Jawaban mahasiswa terhadap soal tersebut dapat dilihat pada gambar 3 berikut:

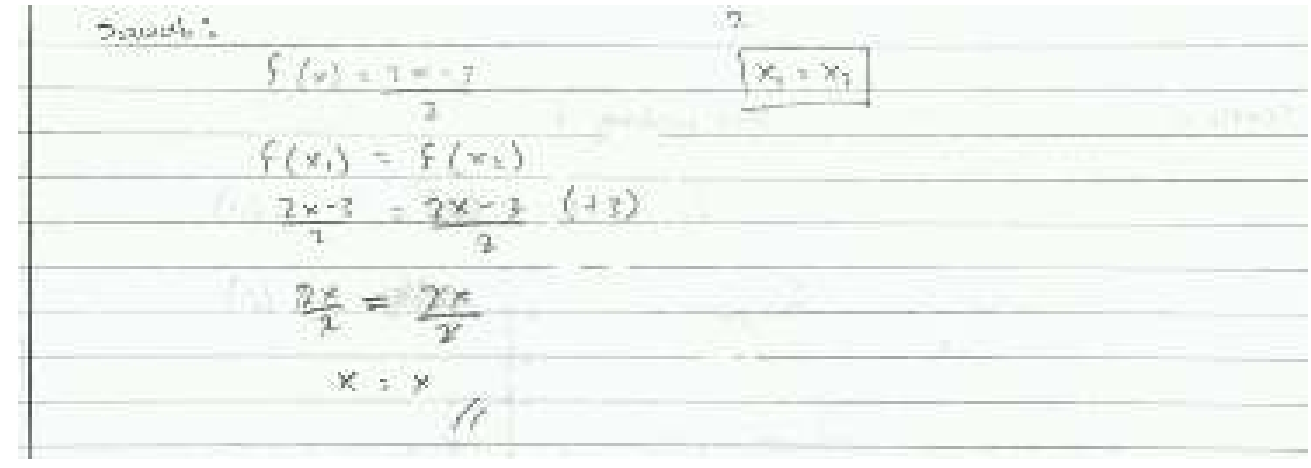

Gambar 3. Jawaban Mahasiswa Mengenai Soal Fungsi Injektif

Pada gambar 3 terlihat bahwa mahasiswa mengalami kesalahan dalam memilih pengoperasian yang dilakukan. Seharusnya kedua ruas bukan ditambah 3 tapi ditambah dengan $\frac{3}{2}$.

D. Kesulitan dalam Menggunakan Prosedur

Matematika memuat prosedur tertentu dalam menyelesaikan suatu permasalahan. Prosedur dalam matematika adalah langkah-langkah yang digunakan untuk menyelesaikan suatu tugas Matematika. Langkah-langkah tersebut sangat penting untuk menemukan jawaban suatu tugas atau permasalahan Matematika. Akan tetapi masih ada 
Histogram: Jurnal Pendidikan Matematika, 4 (2), 2020 - 394

Faíz Azmi Fauzia ${ }^{1}$, Junaidi Fery Efendi ${ }^{2}$

mahasiswa yang keliru dalam mengerjakan langkah-langkah tersebut. Berikut adalah soal tentang induksi Matematika:

Dengan menggunakan induksi matematika, buktikan $5^{n}-4 n-1$ habis dibagi $16 !$

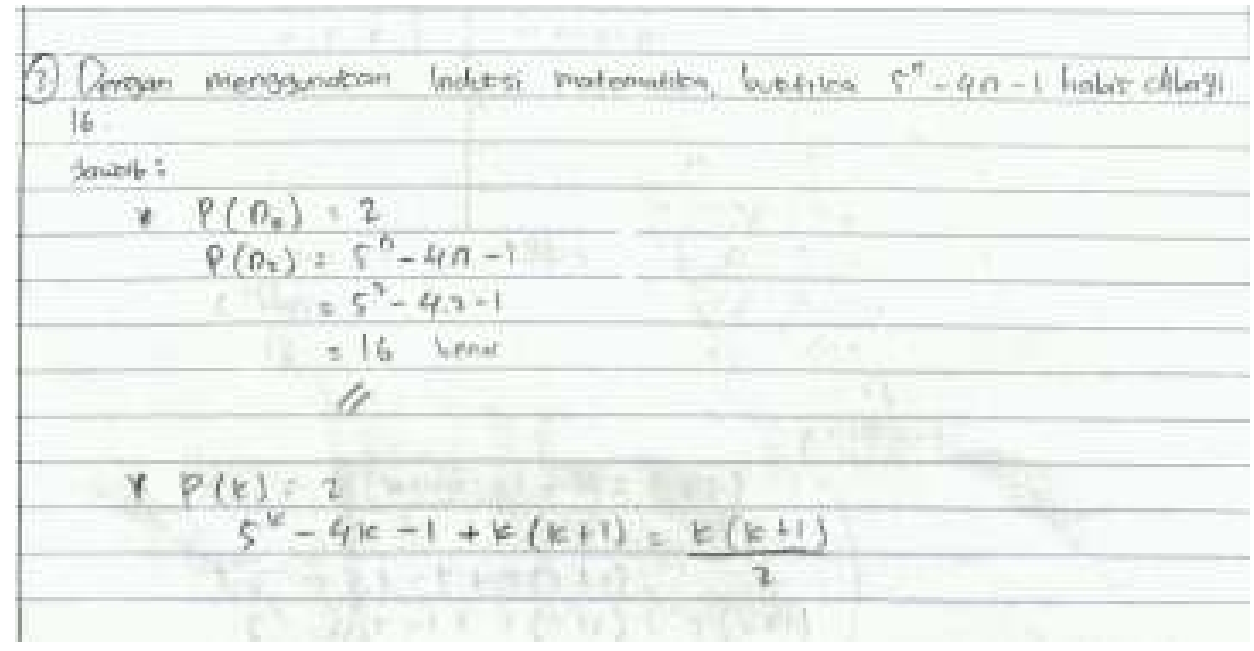

Gambar 4. Jawaban Mahasiswa Mengenai Soal Induksi Matematika

Untuk membuktikan induksi Matematika ada 2 langkah, pertama buktikan $p\left(n_{0}\right)$ benar. Lalu langkah kedua buktikan jika $p(k)$ benar maka $p(k+1)$ benar.

Jawaban siswa pada gambar 4 terlihat langkah pertama sudah benar, akan tetapi pada langkah kedua siswa tidak bisa mengkonstruk pembuktiannya. Siswa lupa konsep bagaimana cara membuktikan langkah kedua. Kesalahan pada prosedur ini juga berkaitan dengan pemahaman konsep. Ini sejalan dengan penelitian yang dilakukan oleh Taufik (2016) bahwa pada induksi Matematika, mahasiswa kesulitan dalam melakukan memanipulasi aljabar untuk menunjukkan kebenaran $P(k+1)$. Mahasiswa kesulitan membuat hubungan $P(k)$ dengan $P(k+1)$. Hal ini juga sejalan dengan yang diungkapkan Putri (2015) bahwa kendala yang dihadapi mahasiswa dalam menyelesaikan pembuktian dengan induksi Matematika yaitu mahasiswa merasa bingung untuk memulai pembuktian.

E. Kesulitan Mengkonstruksi Ide atau Gagasan untuk Membuktikan Suatu Pernyataan Matematika

Analisis Riil syarat akan pembuktian. Baik pembuktian teorema maupun pembuktian kebenaran suatu pernyatan Matematika. Akan tetapi masih ada mahasiswa 


\section{Histogram: Jurnal Pendidikan Matematika, 4 (2), 2020 - 395 Faíz Azmi Fauzia $^{{ }^{*}}$, Junaidi Fery Efendi ${ }^{2}$}

yang mengalami kesulitan dalam menyelesaikan soal pembuktian. Berikut kesalahan yang dilakukan mahasiswa dalam menyelesaikan salah satu soal pembuktian tentang bilangan riil.

Contoh soal:

Tunjukkan jika $a<$ b maka $a<\frac{a+b}{2}<b$

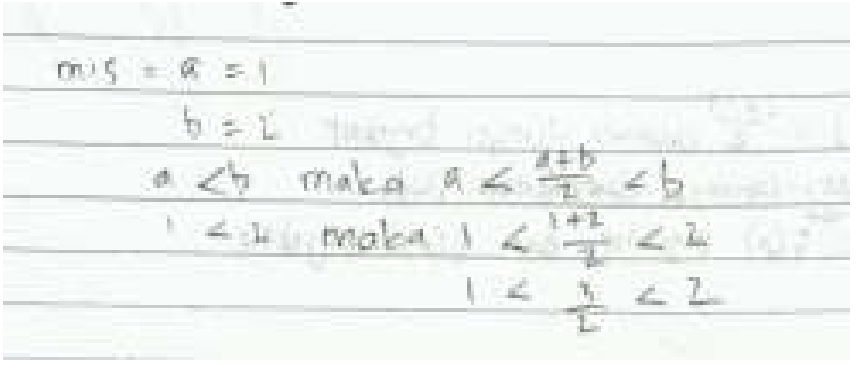

Gambar 5. Jawaban Mahasiswa Mengenai Soal Sifat Bilangan Riil

Dari jawaban tersebut terlihat mahasiswa tidak bisa mengkonstruksi ide untuk menyelesaikan soal tersebut. Mahasiswa mengalami kebingungan tentang konsep apa atau operasi apa yang digunakan agar pembuktian tersebut benar. Mahasiswa hanya memberikan contoh. Padahal untuk membuktikanan kebenaran suatu pernyataan bukan dengan cara memberikan contoh akan tetapi dengan pembuktian langsung atau dengan pembuktian lain yang cocok dengan soal tersebut.

Dengan mengetahui kesulitan-kesulitan yang dihadapi mahasiswa dalam pembelajaran diharapkan dosen bisa melakukan antisipasi sehingga kesalahan tersebut dapat diminimalisir. Adapun alternatif usaha yang dapat dilakukan untuk meminimalisir kesalahan mahasiswa adalah: (1) Dosen perlu memberikan penekanan yang khusus terhadap materi yang sulit bagi mahasiswa. Ini bisa dilihat dari hasil penelitian sebelumnya atau referensi yang sudah ada. Sehingga dosen bisa mengantisipasi agar kesalahan atau kesulitan tersebut tidak dialami oleh mahasiswa; (2) Melakukan pembiasaan (conditioning) melalui kegiatan drill, practice and exercise (Wahyuni, 2017). Memberikan latihan/penugasan yang cukup untuk mahasiswa agar mereka terlatih untuk menyelesaikan persoalan bilangan riil. Latihan/tugas tersebut perlu dibahas dan didiskusikan bersama mahasiswa sehingga mereka paham dimana letak kesalahannya. Sehingga tidak terulang lagi ketika ujian; (3) Memilih metode dan teknik pembelajaran yang sesuai agar mahasiswa bisa memahami konsep dengan baik. 


\section{Histogram: Jurnal Pendidikan Matematika, 4 (2), 2020 - 396 Faíz Azmi Fauzia ${ }^{*}$, Junaidi Fery Efendi ${ }^{2}$}

Beberapa alternatif solusi diatas bisa dilakukan dalam proses perkuliahan. Sehingga kesulitan mahasiswa dalam menyelesaikan persoalan bilangan riil bisa diminimalisir.

\section{KESIMPULAN DAN SARAN}

\section{A. Kesimpulan}

Analisis Riil merupakan mata kuliah wajib bagi mahasiswa STKIP Adzkia Padang pada program studi Pendidikan Matematika Semester 5. Akan tetapi ada kesulitan-kesulitan yang dialami mahasiswa pada mata kuliah ini sehingga hasil UTS mahasiswa kurang bagus. Adapun kesulitan yang dialami mahasiswa tersebut adalah kesulitan dalam menerapkan konsep, mengembangkan konsep, melakukan operasi hitung, menggunakan prosedur tertentu dan kesulitan mengkonstruksi ide atau gagasan untuk membuktikan suatu pernyataan Matematika.

Analisis kesulitan mahasiswa dalam mata kuliah analisis Riil akan membantu dosen Matematika/pendidikan Matematika, khususnya yang mengampu mata kuliah analisis riil dalam mengantisipasi dan mencari solusi yang tepat dalam perkuliahan Analisis Riil. Sehingga kesulitan tersebut bisa diminimalisir bahkan bisa diatasi. Diantara usaha yang dapat dilakukan dosen yaitu: memberikan penekanan pada materi yang sulit bagi mahasiswa, memberikan drill, practice dan exercise yang cukup kepada mahasiswa dan memilih metode dan teknik pembelajaran yang dapat meningkatkan pemahaman mahasiswa.

\section{B. Saran}

Hendaknya dosen yang mengampu matakuliah analisis riil dapat memilih suatu metode pembelajaran atau media pembelajaran yang dapat membantu mahasiswa memahami konsep analisis riil dengan baik serta terampil dalam melakukan pembuktian. Sehingga tujuan pembelajaran dapat tercapai secara maksimal dana mahasiswa bisa mendapatkan nilai yang terbaik.

\section{DAFTAR PUSTAKA}

Gusteti, M. U., \& Syafti, O. (2018). Teknik Hands On Mathematics Terhadap Kemampuan. Jurnal Kepemimpinan dan Kepengurusan Sekolah, 3(2), 217-225. 
Histogram: Jurnal Pendidikan Matematika, 4 (2), 2020 - 397

Faíz Azmi Fauzia ${ }^{*}$, Junaidi Fery Efendi ${ }^{2}$

Musliadi. (2016). Analisis Kesulitan dalam Memahami Konsep Sistem Bilangan Riil Pada Matakuliah Analisis Riil I Mahasiswa Jurusan Pendidikan Angkatan 2014 UIN Alauddin Makassar. Makassar: Skripsi FTK UIN AM.

Patilima, Hamid. (2011). Metode Penelitian Kualitatif. Bandung: Alfabeta.

Putri, R.A.(2015). Problematika dalam Pembuktian Pernyatan Menggunakan Prinsip Induksi Matematika serta Alternatif Penyelesaiannya. Makalah pada Seminar Nasional Matematika dan Pendidikan Matematika. Tanggal 14 November 2015. Yogyakarta: FMIPA UNY.

Sari, E.F.P. (2017). Pengaruh Kemampuan Pemahaman Konsep Matematika Mahasiswa Melalui Metode Pembelajaran Learning Starts With A Question. Mosharafa, 6(1), 25-34.

Siregar, N.F. (2018). Analisis Kesulitan Mahasiswa dalam Menyelesaikan Soal Bilangan Riil. Logaritma, 6 (1), 64-74.

Spronsen, Hillary Dee Van (2008). Proof Processes of Novice Mathematics Proof

Writers. Dissertation of Doctor of Philosophy in Mathematics Education The University of Montana Missoula, MT.

Sucipto, L., \& Mauliddin, M. (2017). Analisis Kesulitan Belajar Mahasiswa Dalam Memahami Konsep Bilangan Real. Beta Jurnal Tadris Matematika, 9(2), 197. https://doi.org/10.20414/betajtm.v9i2.37

Sugiyono. (2016). Metode Penelitian Pendidikan: Pendekatan Kuantitatif, kualitatif dan $R \& D$. Bandung: Alfabeta.

Taufik, A. (2016). Diagnosis Kesulitan Mahasiswa di Universitas Kuningan dalam Pembuktian Menggunakan Induksi Matematika Beserta Upaya Mengatasinya Menggunakan Scaffolding. Jurnal Edukasi dan Sains Matematika, 2 (1),41-54.

Wahyuni, M. (2017). Analisis Problematika Perkuliahan Analisis Riil. Beta: Jurnal Tadris Matematika,9(2), 197-211.

Yuliana, W. (2017). Analisis Kesulitan Mahasiswa dalam Mneyelesaikan Soal Barisan Bilangan Riil di program Studi Pendidikan Matematika Universitas Muhammadiyah Surakarta Tahun Ajaran 2016/2017. Surakarta: Skripsi FKIP $U M S$. 